\title{
Adjustment of four growth models through Bayesian inference on weight and body nutrient depositions in laying quail
}

\author{
Eline Maria Finco', Simara Márcia Marcato², Antonio Claudio Furlan², Robson Marcelo Rossi ${ }^{3}$, \\ Daiane de Oliveira Grieser ${ }^{1}$, Vittor Zancanela ${ }^{1}$, Taciana Maria Moraes de Oliveira ${ }^{1}$, Caroline \\ Espejo Stanquevis ${ }^{1}$
}

\footnotetext{
${ }^{1}$ Universidade Estadual de Maringá, Programa de Pós-graduação em Zootecnia, Maringá, PR, Brazil.

2 Universidade Estadual de Maringá, Departamento de Zootecnia, Maringá, PR, Brazil.

${ }^{3}$ Universidade Estadual de Maringá, Departamento de Estatística, Maringá, PR, Brazil.
}

\begin{abstract}
An experiment was conducted to estimate the parameters of the Gompertz, Brody, Logistic, and Von Bertalanffy equations through Bayesian inference and evaluate the potential for growth in terms of weight and body composition of laying female quail (Coturnix coturnix japonica). The weights and body compositions of the birds were obtained weekly (1-119 days), allowing the adjustment of the four equations by Bayesian inference. The parameters mature weight ( $\beta 1)$, integration constant $(\beta 2)$, maturity rate $(\beta 3)$, and their credibility intervals in four models on body weight and body components were properly estimated by Bayesian inference to describe the body growth in laying quail. The inflection point was determined by the 1st and 2nd derivatives of the Gompertz equation for body weight and body components (fat, protein, ash, and water). Based on Deviance Information Criterion (DIC) for the studied and analyzed variables, there is a model that fits best as a result of its better performance to achieve the DIC value. The Von Bertalanffy model proved to be very versatile, not obtaining good fit of data only for fat. The study shows that other models can also be used in several data sets as an alternative to Gompertz, which, due to its adequate biological interpretation and desirable characteristics in a curve growth, is generally the most used.
\end{abstract}

Key Words: adjust quality, development, maturity rate, nonlinear models, weight at maturity

\section{Introduction}

Animal growth studies are very important because they improve knowledge about management and feeding practices, as well as contribute to the genetic improvement of the species. For laying quail, it is very important to obtain curves that adequately represent their growth of these birds, because they provide information to enable the adoption of appropriate practices to increase the productivity of the birds.

Some nonlinear mathematical models, such as Gompertz, Brody, Von Bertalanffy, Logistic, Richards, and others are widely employed in animal development studies. These models relate weight and age and show appropriate ways to describe the growth curve. These models also assist the interpretation and understanding of the phenomenon and allow sets of information to be concentrated in a small number of parameters (Oliveira et al., 2000).

Received January 27, 2016 and accepted August 5, 2016.

Corresponding author: emfinco@hotmail.com

http://dx.doi.org/10.1590/S1806-92902016001200002

Copyright (C) 2016 Sociedade Brasileira de Zootecnia. This is an Open Access article distributed under the terms of the Creative Commons Attribution License (http://creativecommons.org/licenses/by/4.0/), which permits unrestricted use, distribution, and reproduction in any medium, provided the original work is properly cited.
A bird undergoes phases (growth and laying) along its development and, in each phase, the body has a different nutritional composition. Thus, the study of growth curves, chemical composition, and tissue deposition rates is extremely important because it helps to understand how growth occurs in the animal phases, which, in turn, helps nutritionists to develop appropriate nutritional programs (Neme et al., 2006).

In quail, the development of more accurate curves is needed for more accurate genetic selection. For broilers, genetic selection has caused changes in performance and chemical composition of the carcass. These changes in growth patterns cause changes in nutrient requirements to express the full genetic potential of birds (Sakomura et al., 2005).

Currently, more elaborate methods for analysis data of growth have been sought. The Bayesian methodology is an exquisite form and allows better precision in estimating the parameters of models, enabling satisfactory results.

The objective of this study was to estimate the parameters of four equations (Gompertz, Brody, Logistic, and Von Bertalanffy) (Abramowitz and Stegun, 1964) through Bayesian inference and to evaluate the profile of body growth and growth of the body constituents (water, protein, body fat, and mineral matter), as well as determine the model that best fit the data. 


\section{Material and Methods}

The following experimental procedure was approved by the Brazilian Animal Ethics Committee (Case no. 8798060415/2015).

Twelve hundred 1-day-old female laying quail (commercial hybrid Vicami) were used. In the grower phase (1-42 days), a completely randomized design with five replicates and 240 quail per replicate was adopted. Animals were housed in a conventional shed, with 20 cages of $5.0 \mathrm{~m}^{2}$. Four cages were considered a replicate and a total of five replicates were used.

At 42 days of age (the laying phase), 500 quail were transferred to individual cages in a conventional shed. Five replicates with 100 quail per replicate were used, arranged in a completely randomized design.

The lighting program used was natural during the grower phase. During the laying phase (after 42 days), groups of birds were subjected to a lighting program that started with $15 \mathrm{~h}$ of light and underwent an increase of 30 min per week up to $17 \mathrm{~h}$ of full light (natural + artificial) and $7 \mathrm{~h}$ dark.

A basal diet for the grower phase (1-42 days) was formulated and other diet was used for the laying phase (after 42 days) to adequately meet the nutritional requirements, as recommended by Rostagno et al. (2011) for laying quail. Diets were formulated based on maize and soybean meal, taking into account the chemical composition and energy values proposed by Rostagno et al. (2011). The feed contained 2,901 kcal/kg metabolizable energy during the grower phase and 2,800 kcal/kg during the laying phase, as well as $220.1 \mathrm{~g} \mathrm{~kg}^{-1}$ crude protein during the grower phase and $187.9 \mathrm{~g} \mathrm{~kg}^{-1}$ crude protein during the laying phase.

For determination of body growth, the method described by Sakomura and Rostagno (2007) was used. This method recommends weekly weighing to obtain the average body weight. Quail were weighed weekly to determine the growth curve parameters for live weights, from the first day until the end of the experiment (119 days).

To determine the chemical deposition of nutrients in the carcass of the quail, the method described by Sakomura and Rostagno (2007) was used. For body composition, weekly slaughter of quail via electronarcosis and posterior displacement of the occipital bone and atlas was performed in the period of 1 to 119 days of age, slaughtering 30, 14, 5, 4, and then 2 quail, respectively, for replicate. This volume of material was required for analysis.

After slaughter, the quail with feathers were stored in identified plastic bags and frozen, then subsequently ground in an industrial meat grinder with feathers, feet, viscera, and head. After that, animals were homogenized, weighed, and placed in a greenhouse with forced ventilation at $55^{\circ} \mathrm{C}$ for $72 \mathrm{~h}$ to carry out the pre-drying. Later, they were ground in a mill-type knife and taken to the laboratory to determine crude protein $(\mathrm{CP})$, dry matter $(\mathrm{DM})$, ether extract (EE), and mineral matter $(\mathrm{MM})$ of carcasses. Chemical analyzes were performed according to the methods of the AOAC (1990).

From the data of body weight and body composition, four growth curves were obtained (Gompertz, Brody, Logistic, and Von Bertalanffy) to determine growth and deposition of body nutrients. Bayesian inference was used to estimate the model parameters. In this procedure, the response (Yi) follows a normal distribution, i.e. $Y_{i} \sim$ Normal $\left(f\left(t_{i}\right), \tau\right), i=1,2, \ldots \mathrm{n}$. For the vector of parameter of the non-linear function of the curve, $f\left(t_{i}\right)$ and $\tau$ were considered a priori non-informative distributions, respectively, $\beta \sim \operatorname{Normal}\left(0,10^{-6}\right)$ and $\tau \sim \operatorname{Range}\left(10^{-3}, 10^{-3}\right)$ (OpenBUGS parameterization). Marginal distributions was obtained a posteriori for all parameters by means of the Brugs package of the $\mathrm{R}$ program ( $\mathrm{R}$ Development core team, 2014). A total of 11,000 values were generated in a Monte Carlo Markov Chain (MCMC) process, considering a sampling discard period of 1,000 initial values; thus, the final sample contained 10,000 generated values.

The convergence of the chains was verified by the package CODA (Best et al., 1995) of the R program (R Development Core Team, 2014), by the criteria of Heidelberger and Welch (1983) and Geweke (1992). All the chains generated in the process passed the tests of Heidelberger and Welch (1983) and Geweke (1992).

The following equations were used to fit data and obtain the growth parameters and body composition of animals:

$\mathrm{y}_{\mathrm{i}}=\beta_{1} \exp \left(-\beta_{2} \exp \left(-\beta_{3} \mathrm{t}_{\mathrm{i}}\right)\right)$

(Gompertz);

$\mathrm{y}_{\mathrm{i}}=\beta_{1}\left(1-\beta_{2}{ }^{*} \exp \left(-\beta_{3} \mathrm{t}_{\mathrm{i}}\right)\right)$

(Brody);

$\mathrm{y}_{\mathrm{i}}=\beta_{1} /\left(1+\exp \left(\beta_{2}-\beta_{3} \mathrm{t}_{\mathrm{i}}\right)\right)$

(Logistic);

$\mathrm{y}_{\mathrm{i}}=\beta_{1} *$ pow $\left.\left(1-\beta_{2}{ }^{*} \exp \left(-\beta_{3} \mathrm{t}_{\mathrm{i}}\right)\right)^{\wedge} 3\right) \quad$ (Von Bertalanffy).

In these equations, $\mathrm{y}_{\mathrm{i}}$ represents the body weight of the bird or the deposition of body nutrients in relation to time $\left(\mathrm{t}_{\mathrm{i}}\right)$; parameter $\beta_{1}$ is the mature weight $(\mathrm{g})$ of the animal; $\beta_{2}$ is a constant related to the birth weight of the animal; $\beta_{3}$ is in reason of maximum growth rate relative to the adult weight of the animal and determines the growth efficiency (maturity rate per day); and $\mathrm{t}_{\mathrm{i}} \mathrm{is}$ the time in days.

The Deviance Information Criterion (DIC) is a measure of complexity of the model and was considered in the comparison of the models for best fit of the data. Models with smaller DIC value are most suitable; when comparing both models, the following criteria can be adopted: if the difference between models is less than 5 , it is not significant; 
if the difference is between 5 and 10, it is significant; and if it is greater than 10, it is highly significant (Rossi, 2011).

The first and second derivatives of $\mathrm{y}_{\mathrm{i}}=\mathrm{a} * \exp [-\beta *$ $\left.\exp \left(-y x_{i}\right)\right]$ (Gompertz equation) determine the point $x_{0}$ or $t^{*}$ domain, where $y_{i}$ changes concavity, i.e., the Gompertz curve inflection point is given by Borges (2008): $t^{*}=\frac{\ln c}{r}$, in which $t^{*}$ (day) is the time or age when the growth rate is maximum (inflection point); ln is the natural logarithm; $\beta_{2}=\mathrm{c}$ is the constant of integration; and $\beta_{3}=\mathrm{r}$ is the maturity rate per day.

\section{Results and Discussion}

With regard to body growth, to evaluate the fit of models to the data, the DIC values were obtained. The lowest DIC value was found for the Von Bertalanffy model, indicating a better fit of the data set (Table 1). The difference between the Von Bertalanffy model and the Brody model is smaller than five points. In the comparison of the Von Bertalanffy model with the Gompertz and Logistic models, differences were greater than 10 points, showing to be highly significant (Table 1).

According to Braccini Neto et al. (1996), the Von Bertalanffy curve adequately describes the growth of laying hens because its inflection point is in the early stage of growth, when the animal reaches $30 \%$ of its full growth.

Both Von Bertalanffy and Brody models obtained by Bayesian inference were the best fit to the live weight data in commercial hybrid Vicami. In Braccini Neto et al. (1996), the Brody equation, followed by the Von Bertalanffy equation, obtained by frequentist methodology, fitted the data better and were able to describe growth in laying hens with high accuracy.

There are different growth equations that can be used for different species, and each curve has a form of behavior and fit to the data in accordance with the imposed situation and the obtained data.

The parameter $\beta_{1}$ in the four equations is characterized as an asymptotic weight estimate, or is related to mature

Table 1 - Comparison of fitting performance of different models for body weight of laying quail

\begin{tabular}{llcc}
\hline Model & DIC & Comparison & Difference \\
\hline Gompertz & 630.9 & Gompertz - Von & 13.8 \\
Brody & 619.2 & Brody - Von & $2.1 \mathrm{~ns}$ \\
Logistic & 668.2 & Logistic - Von & 51.1 \\
Von Bertalanffy & $617.1^{*}$ & - & - \\
\hline
\end{tabular}

DIC - deviation information criterion.

ns - not significant difference.

* Model lower DIC. weight, final weight, or theoretical weight of the animal (Braccini Neto et al., 1996).

When evaluating parameter $\beta_{1}$ in the four equations, the highest estimate of the mature weight was obtained by the Brody model (167.10 g), the lowest estimate was obtained with the Logistic model (156.20 g), and the difference between the largest and the smallest mature weight is about $11.0 \mathrm{~g}$. The remaining three equations (Gompertz, Logistic, and Von Bertalanffy) yielded similar values, indicating that there was not much variation.

With the highest value of $\beta_{1}$, the Brody model overestimates the mature weight, as indicated by Costa et al. (2007) in a study with sheep. The Brody equation has the highest estimate of $\beta_{1}$, followed by Von Bertallanffy, Gompertz, and Logistic (Braccini Neto et al., 1996), as in this study.

During the experimental period (119 days), some weight values estimated by equations were overestimated or underestimated, compared with the observed values. At 35, 42, 56, 70, 77, 84, 91, 105, and 119 days of age, the four models proposed were suitable for estimating the body weight of the bird. The largest body weights found are close to the values of the mature weight estimated by the equations (Table 2).

Neme et al. (2006) stated that the mature weight, determined by the Gompertz model, is close to the recommended weight for the beginning of the laying peak. This information is acceptable, considering that the experiment was conducted until 119 days of age (the

Table 2 - Observed and estimated weights from the growth curve models for one to 119 days of age

\begin{tabular}{|c|c|c|c|c|c|}
\hline \multirow[b]{2}{*}{ Age } & \multirow{2}{*}{$\begin{array}{c}\text { Observed } \\
\text { weight }(\mathrm{g})\end{array}$} & \multicolumn{4}{|c|}{ Estimated weight (g) } \\
\hline & & Gompertz & Brody & Logistic & $\begin{array}{c}\text { Von } \\
\text { Bertalanffy }\end{array}$ \\
\hline 1 & 6.65 & 11.60 & -1.22 & 19.00 & 7.83 \\
\hline 7 & 22.00 & 26.51 & 29.73 & 30.29 & 25.43 \\
\hline 14 & 46.86 & 50.31 & 58.71 & 49.09 & 51.72 \\
\hline 21 & 87.51 & 75.91 & 81.59 & 72.80 & 77.51 \\
\hline 28 & 104.21 & 98.87 & 99.63 & 97.54 & 99.39 \\
\hline 35 & 118.53 & 117.14 & 113.87 & 118.71 & 116.54 \\
\hline 42 & 128.81 & 130.62 & 125.10 & 133.99 & 129.36 \\
\hline 49 & 129.90 & 140.08 & 133.96 & 143.69 & 138.66 \\
\hline 56 & 144.41 & 146.51 & 140.96 & 149.37 & 145.28 \\
\hline 63 & 139.10 & 150.80 & $167.10^{*}$ & 152.54 & 149.94 \\
\hline 70 & 148.81 & 153.61 & 150.83 & 154.26 & 153.18 \\
\hline 77 & 160.31 & 155.45 & 154.26 & 155.17 & 155.43 \\
\hline 84 & 153.25 & 156.64 & 156.97 & 155.66 & 156.99 \\
\hline 91 & 155.41 & 157.41 & 159.11 & 155.92 & 158.06 \\
\hline 98 & 166.73 & 157.91 & 160.79 & 156.05 & 158.79 \\
\hline 105 & 157.55 & 158.23 & 162.12 & 156.12 & 159.30 \\
\hline 112 & 164.50 & 158.43 & 163.17 & 156.16 & 159.64 \\
\hline 119 & 165.42 & $158.56^{*}$ & 164.00 & $156.18 *$ & $159.88^{*}$ \\
\hline
\end{tabular}

* Values close to estimate $\beta_{1}$. 
beginning of the laying peak). The mature weight $\left(\beta_{1}\right)$ estimated by Gompertz was $158.80 \mathrm{~g}$ (Table 3), close to the body weight estimated by Gompertz at 119 days of age (158.56 g) (Table 2), which is the beginning of the laying peak for these quail.

The same is true for Logistic and Von Bertalanffy models, which showed proximity between their mature weight values and body weight estimated at 119 days by the models (Table 2). The birds began their reproductive development before laying, reaching their maximum development in the laying peak.

The estimated weight is consistent with that observed for some models, except for the Brody model, which has the highest value $(167.10 \mathrm{~g})$ in relation to the observed weight, and the Logistic model, which has the lowest value (156.18 g) (Table 2). The Brody model was not adequate to estimate the weight of the birds at the first day $(-1.22)$, thus, it is not highly indicated for predicting body weight of quail in early stages.

Females generally have a greater mature weight due to the intense development of the reproductive system and greater fat deposition close to sexual maturity (Neme et al., 2006). Even when young, quail reach a high mature weight, suggesting that these birds underwent intense genetic selection for body weight (Drumond et al., 2013).

The $\beta_{1}$ of females was lower in relation to that found in the literature. This variation can be explained by the genetic differences between Japanese quail lines and by

Table 3 - Parameter estimates of the growth curves for body weight of laying quail through Bayesian inference

\begin{tabular}{lccc}
\hline & Mean (SD) & $\mathrm{P}_{2.5 \%}$ & $\mathrm{P}_{97.5 \%}$ \\
\hline & & Gompertz & \\
Beta 1 & $158.80(1.465)$ & 156.00 & 161.80 \\
Beta 2 & $2.788(0.170)$ & 2.483 & 3.146 \\
Beta 3 & $0.063(0.003)$ & 0.057 & 0.070 \\
DIC & 630.9 & & \\
& & Brody & \\
Beta 1 & $167.10(1.851)$ & 163.60 & 170.90 \\
Beta 2 & $1.042(0.017)$ & 1.008 & 1.076 \\
Beta 3 & $0.034(0.001)$ & 0.031 & 0.037 \\
DIC & 619.2 & & \\
& & Logistic & \\
Beta 1 & $156.20(1.648)$ & 153.00 & 159.50 \\
Beta 2 & $2.069(0.130)$ & 1.827 & 2.338 \\
Beta 3 & $0.092(0.092)$ & 0.080 & 0.105 \\
DIC & 668.2 & & \\
Beta 1 & & Von Bertalanffy & \\
Beta 2 & $160.40(1.427)$ & 157.60 & 163.20 \\
Beta 3 & $0.670(0.029)$ & 0.615 & 0.733 \\
DIC & $0.054(0.002)$ & 0.049 & 0.059 \\
\hline
\end{tabular}

Beta 1 (g) - weight to maturity; Beta 2 - constant related to the birth weight of the animal; Beta 3 - maturity rate per day; DIC - deviation information criterion. SD - standard deviation of the mean; P2.5\%-P97.5\% - range with $95 \%$ credibility. non-genetic factors such as temperature, relative humidity, nutrition, season of the year, photoperiod, and others.

The parameter $\beta_{2}$ is an integration constant related to the proportion of growth after the birth of the animal (Falcão et al., 2015). Based on the results, the highest $\beta_{2}$ values were observed in the Gompertz (2.788) and Logistic (2.069) models, which had lower weights at maturity $(158.80 \mathrm{~g}$ and $156.20 \mathrm{~g}$, respectively), indicating a negative correlation between $\beta_{1}$ and $\beta_{2}$.

The estimates obtained by the four equations for Bayesian inference indicated that the $\beta_{2}$ values, found by Gompertz (2.788) and Logistic (2.069), are similar and have a small difference (0.72), showing a greater relationship between the models to determine the constant. The values obtained by Brody (1.042) and Von Bertalanffy (0.670) are different from the values obtained by the above equations, values differing from each other and showing a weaker relationship in determining the constant.

Parameter $\beta_{3}$ is a maturity index that estimates the relative rate at which the mature weight is reached, that is, the rate at which a logarithmic function of weight changes linearly per unit of time (Braccini Neto et al., 1996).

The parameters $\beta_{1}, \beta_{3}$, and $t^{*}$ have biological interpretation and are considered the most important parameters to be evaluated in growth curves. In the biological interpretation, $\beta_{3}$ is taken as a measure of growth, because it influences the growth rate or gain speed (Braccini Neto et al., 1996). The higher its value, the lower the time to reach maximum growth, being the animal more premature. Low values of $\beta_{3}$ indicate later maturity (Silva et al., 2004).

The highest maturity rate was estimated by the Logistic model, followed by the Gompertz and Von Bertalanffy models and the lowest value was obtained by the Brody model (Table 3). The largest $\beta_{3}$ observed in the Logistic model indicates that the animal reached maturity faster.

For parameter $\beta_{1}$, the Brody model was found with the highest value, while the Logistic model showed the lowest. This confirms the fact that there is a high negative correlation between maturity rate $\left(\beta_{3}\right)$ and mature weight $\left(\beta_{1}\right)$ (Silva et al., 2004; Veloso et al., 2013).

Parameter $t^{*}$ (inflection point) determines the time the animal undergoes a fast growth phase for an inhibitory growth phase, when its weight gains are reduced. The inflection point in the Gompertz, Logistic, and Von Bertalanffy functions is fixed, determining the shape of the growth curve (Drumond et al., 2013), while the Brody model does not have an inflection point (Freitas, 2005).

For the Gompertz equation, derivatives were applied to the equation to obtain the inflection point $\left(\mathrm{t}^{*}\right)$, in which 16.27 days are necessary for maximum growth rate, when 
the growth curve shifts from increasing to decreasing or concave to convex.

According to Neme et al. (2006), lighter birds reach the inflection point earlier than heavier birds. The commercial hybrid Vicami had a lower body weight than those found in the literature and these quail reached their inflection point at 16.27 days. This can be attributed to genetic breeding works carried out in the company. Another factor that may have contributed to this is that only females were raised and the birds showed to be homogeneous at all weighing occasions.

Drumond et al. (2013) stated that the rapid growth of quail is very important because the faster the growth, the shorter the time required to reach adulthood, which consequently changes alimentation costs, reduces the generation interval, and enables an increase of genetic gain per generation.

For commercial hybrid Vicami, the inflection point was obtained before the middle of the trial period (119 days), indicating that they are young animals. According to Grossman et al. (1982), the distribution of the growth rate relative to the inflection point is asymmetric, so the inflection point is not located in the center of the curve.

This can be explained by the fact that the growth models have a fixed t* (Drumond et al., 2013), which is usually observed in the initial phase of the curve. For Gompertz, $t^{*}$ is set at $35-40 \%$ (initial part) growth of physical maturity; for Von Bertalanffy, it is fixed at $30 \%$ of maturity weight; and for Logistic, it is between 41 and $44 \%$ of $\beta_{1}$.

With regard to the body chemical composition, to evaluate the fit of models to body fat data, the lowest DIC value was estimated for the Logistic model (309.7) (Table 4). The highest difference was observed between the Brody and Logistic models, a highly significant difference. Of the four models, the Brody model showed the worst fit to fat deposition data. The difference between the Logistic and Von Bertallanffy models was highly significant, whereas the difference between the Gompertz and Logistic models was significant but not high. The Logistic model can be considered the best fit to the fat data and it adequately described body growth.

For crude protein, the lowest DIC value was estimated for the Von Bertalanffy model (354.2) (Table 4). The highest significant difference was obtained between the Von Bertalanffy and Logistic models. The Logistic model had better data fit for fat, but worse data fit for protein. This is due perhaps to the fact that there is a negative correlation between protein and fat. There is a highly significant difference between the Von Bertalanffy and Brody models, while the difference between the Von Bertalanffy and
Gompertz models is significant. The Von Bertalanffy model can be used to describe the increase of body protein.

When evaluating the quality of model fit to ash data, the Von Bertalanffy model had the lowest DIC value (127.2) (Table 4). The highest difference was obtained between the Von Bertalanffy and Brody models, which was highly significant. The difference between the Von Bertalanffy and Logistic models was also highly significant and there was no significant difference between the Von Bertalanffy and Gompertz models. The two functions were adequate to the ash data and both described the deposition of body ash precisely. The Von Bertalanffy model showed suitable data fit for protein and ash, which have higher deposition in the early phases of growth and may have some relationship.

In the same evaluation performed for water, the lowest DIC value was obtained by the Brody model (578.9) (Table 4). The major difference was observed for the Brody and Logistic models, which was highly significant, again showing a negative correlation between fat and water, since the Brody model had worst fit to fat data. The difference between the Brody and Gompertz models was highly significant, but not significant between Von Bertalanffy and Brody. Thus, the Von Bertalanffy model can be used in addition to the Brody equation, which has the lowest DIC, as they have no significant differences of data fit. The Brody model is adequate because it has no inflection

Table 4 - Comparisons between different models of growth through DIC for body components in laying quail

\begin{tabular}{|c|c|c|c|}
\hline Model & DIC & Comparasion & Difference \\
\hline & \multicolumn{3}{|c|}{ Fat } \\
\hline Gompertz & 317.5 & Gompertz - Logistic & $7.8 * *$ \\
\hline Brody & 345.3 & Brody - Logistic & 35.6 \\
\hline Logistic & $309.7 *$ & - & - \\
\hline \multirow[t]{2}{*}{ Von Bertalanffy } & 322.3 & Von - Logistic & 12.6 \\
\hline & \multicolumn{3}{|c|}{ Crude protein } \\
\hline Gompertz & 361.6 & Gompertz - Von & $7.4 * *$ \\
\hline Brody & 370.5 & Brody - Von & 16.3 \\
\hline Logistic & 388.8 & Logistic - Von & 34.6 \\
\hline \multirow[t]{2}{*}{ Von Bertalanffy } & $354.2 *$ & - & - \\
\hline & \multicolumn{3}{|c|}{ Ash } \\
\hline Gompertz & 129.0 & Gompertz - Von & 1.8 \\
\hline Brody & 141.3 & Brody - Von & 14.1 \\
\hline Logistic & 139.0 & Logistic - Von & 11.8 \\
\hline \multirow[t]{2}{*}{ Von Bertalanffy } & $127.2^{*}$ & - & - \\
\hline & \multicolumn{3}{|c|}{ Water } \\
\hline Gompertz & 589.2 & Gompertz - Brody & 10.3 \\
\hline Brody & $578.9^{*}$ & - & - \\
\hline Logistic & 616.6 & Logistic - Brody & 37.7 \\
\hline Von Bertalanffy & 579.6 & Von - Brody & 0.7 \\
\hline
\end{tabular}

DIC - deviation information criterion

* Model lower DIC.

** Significant difference. 
point and can be used to analyze the nutrient deposition rate (Freitas, 2005).

The parameter $\beta_{1}$ determines the weight that the body component should reach close to maturity (Murakami and Franco, 2004). With respect to the estimates of $\beta_{1}$ obtained for the body chemical components, in all models, water had a higher $\beta_{1}$, followed by protein, fat, and ash, in decreasing order (Tables 5, 6, 7, and 8).

The values obtained for fat deposition at mature weight showed a slight variation when comparing the four equations

Table 5 - Parameter estimates of the Gompertz equation by Bayesian inference for body composition (fat, crude protein, ash, and water) of laying quail

\begin{tabular}{lcccc}
\hline Body composition & & Mean $(\mathrm{SD})$ & $\mathrm{P}_{2.5 \%}$ & $\mathrm{P}_{97.5 \%}$ \\
\hline \multirow{4}{*}{ Fat } & Beta 1 & $12.82(0.306)$ & 12.25 & 13.46 \\
& Beta 2 & $4.782(0.844)$ & 3.501 & 6.74 \\
& Beta 3 & $0.053(0.005)$ & 0.044 & 0.064 \\
& DIC & 317.5 & & \\
Crude protein & Beta 1 & $32.13(0.28)$ & 31.49 & 32.79 \\
& Beta 2 & $3.104(0.220)$ & 2.717 & 3.582 \\
& Beta 3 & $0.063(0.003)$ & 0.056 & 0.07 \\
Ash & DIC & 361.6 & & \\
& Beta 1 & $5.46(0.080)$ & 5.31 & 5.62 \\
& Beta 2 & $4.035(0.633)$ & 3.048 & 5.495 \\
& Beta 3 & $0.078(0.007)$ & 0.065 & 0.094 \\
Water & DIC & 129.0 & & \\
& Beta 1 & $106.50(1.070)$ & 104.40 & 108.60 \\
& Beta 2 & $2.826(0.222)$ & 2.436 & 3.308 \\
& Beta 3 & $0.072(0.004)$ & 0.063 & 0.081 \\
\hline
\end{tabular}

Beta $1(\mathrm{~g})$ - weight to maturity; Beta 2 - constant related to the birth weight of the animal; Beta 3 - maturity rate per day; DIC - deviation information criterion. SD - standard deviation of the mean; P2.5\%-P97.5\% - range with $95 \%$ credibility.

Table 6 - Parameter estimates of the Brody equation by Bayesian inference for body composition (fat, crude protein, ash, and water) of laying quail

\begin{tabular}{lcccc}
\hline \multirow{2}{*}{ Body composition } & & Mean $(\mathrm{SD})$ & $\mathrm{P}_{2.5 \%}$ & $\mathrm{P}_{97.5 \%}$ \\
\hline \multirow{4}{*}{ Fat } & Beta 1 & $14.90(0.834)$ & 13.50 & 16.74 \\
& Beta 2 & $1.089(0.038)$ & 1.016 & 1.169 \\
& Beta 3 & $0.020(0.002)$ & 0.015 & 0.025 \\
& DIC & 345.3 & & \\
Crude protein & Beta 1 & $34.12(0.98)$ & 33.19 & 35.16 \\
& Beta 2 & $1.063(0.21)$ & 1.022 & 1.105 \\
& Beta 3 & $0.032(0.01)$ & 0.029 & 0.035 \\
& DIC & 370.5 & & \\
Ash & Beta 1 & $5.80(0.121)$ & 5.57 & 6.05 \\
& Beta 2 & $1.097(0.035)$ & 1.029 & 1.168 \\
& Beta 3 & $0.035(0.002)$ & 0.030 & 0.041 \\
& DIC & 141.3 & & \\
Water & Beta 1 & $111.40(1.319)$ & 108.90 & 114.00 \\
& Beta 2 & $1.038(0.021)$ & 0.996 & 1.082 \\
& Beta 3 & $0.038(0.001)$ & 0.035 & 0.042 \\
& DIC & 578.9 & & \\
\hline
\end{tabular}

Beta $1(\mathrm{~g})$ - weight to maturity; Beta 2 - constant related to the birth weight of the animal; Beta 3 - maturity rate per day; DIC - deviation information criterion. SD - standard deviation of the mean; P2.5\%-P97.5\% - range with $95 \%$ credibility
(Tables 5, 6, 7, and 8). The largest difference was found between the Brody and Logistic equations (2.35 g). The difference between both equations was $2.54 \mathrm{~g}$ for protein, $0.41 \mathrm{~g}$ for ash, and $6.60 \mathrm{~g}$ for water.

These equations follow the same pattern observed for $\beta 1$ for body growth, confirming the relationship between body growth and deposition of body constituents. The evaluated equations adequately describe the deposition of body components, but in some cases, the Brody model overestimates $\beta 1$.

Table 7 - Parameter estimates of the Logistic equation by Bayesian inference for body composition (fat, crude protein, ash, and water) of laying quail

\begin{tabular}{lcccc}
\hline Body composition & & Mean (SD) & $\mathrm{P}_{2.5 \%}$ & $\mathrm{P}_{97.5 \%}$ \\
\hline \multirow{4}{*}{ Fat } & Beta 1 & $12.55(0.244)$ & 12.08 & 13.04 \\
& Beta 2 & $2.997(0.254)$ & 2.540 & 3.539 \\
& Beta 3 & $0.080(0.006)$ & 0.068 & 0.095 \\
& DIC & 309.7 & & \\
Crude protein & Beta 1 & $31.58(0.343)$ & 30.91 & 32.27 \\
& Beta 2 & $2.250(0.138)$ & 1.994 & 2.537 \\
& Beta 3 & $0.092(0.006)$ & 0.081 & 0.105 \\
\multirow{5}{*}{ Ash } & DIC & 388.8 & & \\
& Beta 1 & $5.38(0.078)$ & 5.23 & 5.54 \\
& Beta 2 & $2.685(0.264)$ & 2.216 & 3.247 \\
& Beta 3 & $0.117(0.012)$ & 0.095 & 0.143 \\
Water & DIC & 139.0 & & \\
& Beta 1 & $104.80(1.152)$ & 102.50 & 107.10 \\
& Beta 2 & $2.133(0.167)$ & 1.825 & 2.482 \\
& Beta 3 & $0.107(0.009)$ & 0.091 & 0.127 \\
& DIC & 616.6 & &
\end{tabular}

Beta $1(\mathrm{~g})$ - weight to maturity; Beta 2 - constant related to the birth weight of the animal; Beta 3 - maturity rate per day; DIC - deviation information criterion. SD - standard deviation of the mean; P2.5\%-P97.5\% - range with $95 \%$ credibility.

Table 8 - Parameter estimates of the Von Bertalanffy equation by Bayesian inference for body composition (fat, crude protein, ash, and water) of laying quail

\begin{tabular}{lcccc}
\hline Body composition & & Mean (SD) & $\mathrm{P}_{2.5 \%}$ & $\mathrm{P}_{97.5 \%}$ \\
\hline \multirow{4}{*}{ Fat } & Beta 1 & $13.01(0.351)$ & 12.36 & 13.74 \\
& Beta 2 & $1.012(0.141)$ & 0.776 & 1.324 \\
& Beta 3 & $0.044(0.004)$ & 0.036 & 0.053 \\
& DIC & 322.3 & & \\
Crude protein & Beta 1 & $32.45(0.338)$ & 31.79 & 33.13 \\
& Beta 2 & $0.729(0.040)$ & 0.658 & 0.814 \\
& Beta 3 & $0.053(0.002)$ & 0.048 & 0.059 \\
\multirow{5}{*}{ Ash } & DIC & 354.2 & & \\
& Beta 1 & $5.50(0.086)$ & 5.34 & 5.68 \\
& Beta 2 & $0.903(0.115)$ & 0.719 & 1.171 \\
& Beta 3 & $0.066(0.006)$ & 0.055 & 0.080 \\
Water & DIC & 127.2 & & \\
& Beta 1 & $107.50(1.070)$ & 105.40 & 109.60 \\
& Beta 2 & $0.672(0.039)$ & 0.602 & 0.757 \\
& Beta 3 & $0.061(0.003)$ & 0.054 & 0.068 \\
& DIC & 579.6 & &
\end{tabular}

Beta $1(\mathrm{~g})$ - weight to maturity; Beta 2 - constant related to the birth weight of the animal; Beta 3 - maturity rate per day; DIC - deviation information criterion. SD - standard deviation of the mean; P2.5\%-P97.5\% - range with $95 \%$ credibility. 
Male broilers have greater mature weight $(\mathrm{P}<0.05)$, water, and protein and less lipid weight relative to females (Gous et al., 1999). These differences between the body components are attributed to differences in body composition between genders and the various positive and negative correlations between the nutrients and tissues.

When evaluating the protein and fat content in carcasses based on natural matter, protein is higher than fat, because, for each gram of protein, there are four grams of associated water, adding up to five grams, and causing a 5:1 protein to fat ratio (Leeson, 1995).

For the deposition of fat, commercial hybrid Vicami showed mature rate values ranging from 0.020 to 0.080 ; for the deposition of body protein, $\beta_{3}$ values ranged from 0.032 to 0.092 ; for the deposition of ash, the values ranged from 0.035 to 0.117 ; and for the deposition of body water, $\beta 3$ ranged from 0.038 to 0.107 .

From the estimates of the parameters, the Brody equation had the lowest value of maturity rate for fat, protein, ash, and water and the Logistic equation has the highest value for all body constituents. In contrast, the Brody model has greater weight to maturity for all body constituents and the Logistic model has the lowest $\beta_{1}$, confirming the high negative correlation between weight to maturity and maturity rate (Silva et al., 2004; Veloso et al., 2013).

Using the Brody equation obtained by Bayesian inference for the deposition of nutrients can lead to an underestimated maturity rate, contrary to the Logistic equation, which can provide an overestimated value of maturity rate related to deposit body components.

According to Kessler and Snizek (2001), there is a limit to the daily protein deposition (lean meat), regardless of the amount of protein intake. This is due to the fact that deposition is genetically controlled. For fat, such deposition depends on the amount of nutrients and energy available for their synthesis and deposition.

Obtaining the four growth curves and its appropriate parameters for all body components is based on collecting sufficient amount of data and obtaining complete data and a satisfactory evaluation time, since the quail were evaluated from one to 119 days of age. According to Koncagul and Cadirci (2009), to obtain reliable estimates of the parameters of growth curves, the data must be collected until a point at which the growth curve starts to become flat or when the inflection point occurs and the growth rate slows down.

The values for $\mathrm{t}^{*}$ by the $1 \mathrm{st}$ and 2 nd derivative of the Gompertz equation were obtained at 29.52 days for fat and 17.98 days of age for crude protein. Ash reached its inflection point at 17.88 days and water at 14.43 days of age.
The maximum deposition of protein for laying quail (commercial hybrid Vicami) occurred at 18 days $\left(t^{*}\right)$. From this point, there is a change in the protein deposition from ascending to descending, in which the birds spend their energy intake on deposition of body and visceral fat, including in the ovary and oviduct, and use the energy reserve for reproductive development and to start reproduction. This change of direction in the deposition is related to the initial physiological signs of the development of the reproductive systems of the bird (Neme et al., 2006).

According to Silva et al. (2012), the meat-type quail have the maximum growth rate peak at 27 days-old. Probably, this is the period in which there is greater deposition of protein and water in the carcass. In this study, commercial hybrid Vicami showed earlier maximum deposition of protein and water, indicating a difference in the deposition of body nutrients between the meat-type and laying quail.

For water, $t^{*}$ occurs at 14 days, indicating that the bird starts to deposit less body water. The inflection points of the protein and water are close and higher values for weight to maturity are obtained for water and protein in the four equations, because there is a relationship between these carcass constituents.

The results of Silva et al. (2003) suggest that an increase in the protein content accompanies the increase in water in the carcass. For each $1 \%$ increase in water in the carcass, the lipid content decreases by $1 \%$, demonstrating a high negative correlation between water and fat.

The fat deposition period was later (30 days) than that of protein, confirming that the animal continues depositing fat in the carcass after reducing the deposition of protein and water, demonstrating that this occurs naturally in most animals.

Pesti and Bakalli (1997) have also shown a close relationship between the percentage of water and lipids in carcass, stating that an increase of lipids in the carcass results in a decrease in the percentage of water and a reduction in protein deposition.

\section{Conclusions}

Body weight and body composition parameters in commercial hybrid Vicami can be obtained by Bayesian inference. In general, all models show good fit by the Bayesian approach using a non-informative prior. Obtaining appropriate parameters and models with best fit allows for the selection of the models that adequately describe the body growth of animals. The Von Bertalanffy model is very versatile in describing the growth of some body components and body growth. The study shows which of the models 
can also be used as an alternative to the Gompertz model, generally the most used.

\section{Acknowledgments}

The authors thank the Vicami company, especially Mr. Osvaldo, for their support in conducting this experiment and the supply of animals; and $\mathrm{CNPq}$, for granting the project financing.

\section{References}

Abramowitz, M. and Stegun, I. A. 1964. Handbook of mathematical functions with formulas, graphs and mathematical tables. Washington, DC.

AOAC - Association of Official Analytical Chemistry. 1990. Official methods of analysis. 15th ed. AOAC International, Arlington, VA.

Best, N.; Cowles, M. K. and Vine, K. 1995. Convergence diagnosis and output analysis software for gibbs sampling output. MRC Biostatistics Unit, Institute of Plublic Health. Cambridge, UK.

Borges, A. I. C. 2008. Interface "comparação de curvas de crescimento": aplicação matemática para o auxílio na comparação de curvas de crescimento de populações de peixes. Dissertação (M.Sc.). Faculdade de Ciências da Universidade do Porto, Portugal.

Braccini Neto, J.; Dionello, N. J. L.; Silveira Júnior, P.; Bongalhardo, D. C. and Xavier, E. G. 1996. Análise de curvas de crescimento de aves de postura. Revista da Sociedade Brasileira de Zootecnia 25:1062-1073.

Costa, R. L. D.; Afonso, V. A .C. and Quirino, C. R. 2007. Utilização de funções não-lineares para descrição de curvas de crescimento em ovinos. Pesquisa \& Tecnologia 4:1-10.

Drumond, E. S. C.; Gonçalves, F. M.; Veloso, R. C.; Amaral, J. M.; Balotin, L. V.; Pires, A. V. and Moreira, J. 2013. Curvas de crescimento para codornas de corte. Ciência Rural 43:1872-1877.

Falcão, P. F.; Pedrosa, V. B.; Moreira, R. P.; Sieklicki, M. F.; Rocha, C. G.; Santos, I. C.; Ferreira, E. M. and Martins, A. S. 2015. Curvas de crescimento de cordeiros da raça Ile de France criados em confinamento. Revista Brasileira Saúde Produção Animal $16: 377-386$

Freitas, A. R. 2005. Curvas de crescimento na produção animal. Revista Brasileira de Zootecnia 34:786-795.

Geweke, J. 1992. Evaluating the accuracy of sampling-based approaches to the calculation of posterior moments (with discussion). p.169-193. In: Bayesian statistics. 4th ed. University Press, Oxford.

Gous, R. M.; Moran Jr., E. T.; Stilborn, H. R. and Bradford, G. D. and Emmans, G. C. 1999. Evaluation of the parameters needed to describe the overall growth, the chemical growth, and the growth of feathers and breast muscles of broilers. Poultry Science $78: 812-821$.

Grossman, M.; Bohren, B. B. and Anderson, B. L. 1982. Logistic growth curves of chicken: a comparison of the techniques to estimate parameters. Journal of Heredity 76:397-399.
Heidelberger, P. and Welch, P. 1983. Simulation run length control in the presence of an initial transient. Operations Research 31:1109-1144.

Kessler, A. M. and Snizek, P. N. 2001. Considerações sobre a quantidade de gordura na carcaça do frango. p.111-133. In: Anais da Reunião Anual da Sociedade Brasileira de Zootecnia, Piracicaba.

Koncagul, S. and Cadirci, S. 2009. Comparison of three non-linear models when data truncated at different lengths of growth period in Japanese quail. Archive Geflügelk 73:7-12.

Leeson, S. 1995. Nutrição e qualidade da carcaça de frangos de corte. p.111. In: Conferência Apinco de Ciência e Tecnologia Avícola, Curitiba.

Murakami, A. E. and Franco, J. R. G. 2004. Nutrição de codornas japonesas em postura. p.1. In: XIV Congresso Brasileiro de Zootecnia (Zootec), Brasília

Neme, R.; Sakomura, N. K.; Fukayama, E. H.; Freitas, E. R.; Fialho, F. B.; Resende, K. T. and Fernandes, J. B. K. 2006. Curvas de crescimento e deposição dos componentes corporais de aves de postura de diferentes linhagens. Revista Brasileira de Zootecnia 35:1091-1100

Oliveira, H. N.; Lobo, R. B. and Pereira, C. S. 2000. Comparação de modelos não-lineares para descrever o crescimento de fêmeas da raça guzerá. Pesquisa Agropecuária Brasileira 35:1843-1851.

Pesti, G. M. and Bakalli, R. I. 1997. Estimation of the composition of broiler carcasses from their specific gravity. Poultry Science 76:948-951.

R Development Core Team. 2014. R: A language and environment for statistical computing. R Foundation for Statistical Computing, Vienna, Austria. Available at: <http://www.R-project.org $>$. Accessed on: Nov. 11, 2014.

Rossi, R. M. 2011. Introdução aos métodos Bayesianos na análise de dados Zootécnicos com uso do Winbugs e R. Eduem, Maringá.

Rostagno, H. S.; Albino, L. F. T.; Donzele, J. L.; Gomes, P. C.; Oliveira, R. F.; Lopes, D. C.; Ferreira, A. S. and Barreto, S. L. T. and Euclides, R. F. 2011. Tabelas brasileiras para aves e suínos: composição de alimentos e exigências nutricionais. 2.ed. Viçosa, MG.

Sakomura, N. K.; Longo, F. A.; Oviedo-Rondon, E. O. and BoaViagem, C. and Ferraudi, A. 2005. Modeling energy utilization and growth parameter description for broiler chickens. Poultry Science 84:1363-1369.

Sakomura, N. K. and Rostagno, H. S. 2007. Métodos de pesquisa em nutrição de monogástricos. Funep, Jaboticabal, SP.

Silva, J. H. V.; Albino, L. F. T. and Nascimento, A. H. 2003. Estimativas da composição anatômica da carcaça de frangos de corte com base no nível de proteína da ração e peso da carcaça. Revista Brasileira de Zootecnia 32:344-352.

Silva, N. A. M.; Aquino, L. H.; Silva, F. F. and Oliveira, A. I. G. 2004. Curvas de crescimento e influência de fatores não-genéticos sobre as taxas de crescimento de bovinos da raça Nelore. Ciência e Agrotecnologia 28:647-654.

Silva, J. H. V.; Filho, J. J.; Costa, F. G. P.; Lacerda, P. B.; Vargas, D. G. V. and Lima, M. R. 2012. Exigências nutricionais de codornas. Revista Brasileira de Saúde e Produção Animal 13:775-790.

Veloso, R. C.; Costa, L. S.; Drumond, E. S. C.; Pires, A. V.; Torres Filho, R. A. and Carneiro, A. P. S. 2013. Modelos não-lineares para descrever o crescimento de frangos tipo caipira. 3p. In: Anais do X Simpósio Brasileiro de Melhoramento Animal, Uberaba. 